\title{
Resensi
}

\section{Menjadi Pemimpin Garda Depan}

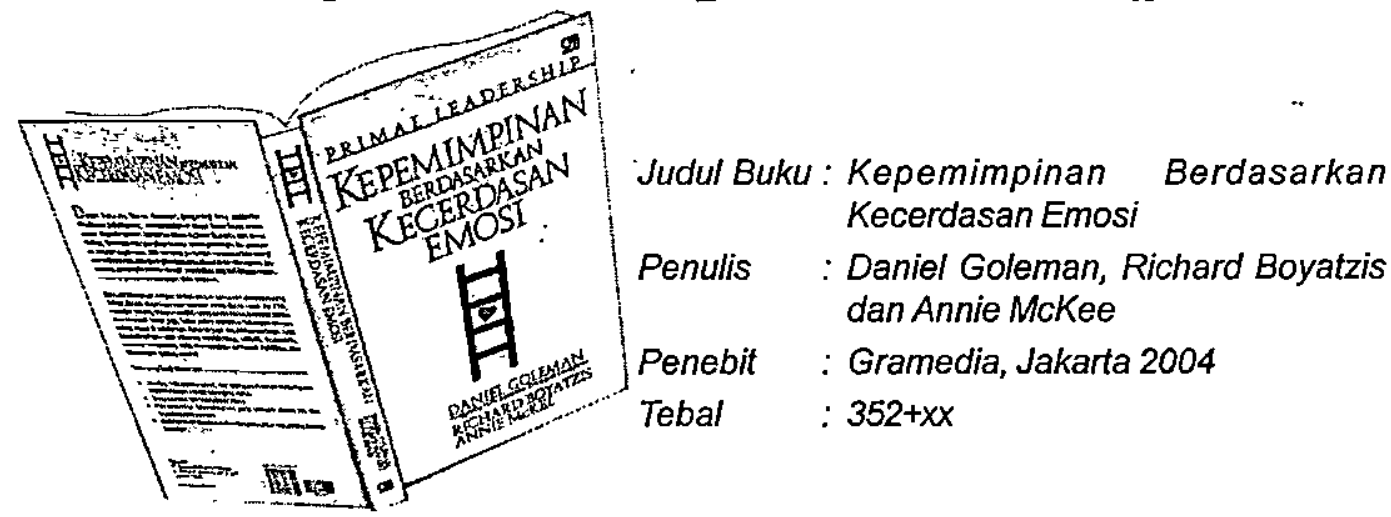

Quku ini mengkaji tentang kepemimpinan dari aspek psikologi. Asumsi dasarnya adalah berdasarkan penelitian tiga penulis buku ini ada faktor yang sangat memprihatinkan tentang aspek kepemimpinan selama ini yaitu banyak pemimpin yang memimpin tetapi sebenarnya mereka bukanlah pemimpin. Maksudnya secara formal para pemimpin itu duduk (menjabat) pada posisi itu entah negara, partai politik, perusahaan, lembaga pendidikan dan lainlain. Namun, posisi itu tak lebih sebagai formalitas, sejatinya mereka tak pernah benar-benar memimpin institusi itu secara benar, optimal yang memiliki daya dorong untuk maju. Pemimpin demikian ini lebih mirip disebabkan "keterpaksaan" atau dikarbit karena memang tidak ada pilihan lain. Yang jelas, pemimpin demikian pertimbangannya hanya sempit dan berjangka pendek, seperti demi "massal konstituennya" dalam perspektif politik, demi "keturunan" karena sang ayah yang memiliki corporate raksasa dan tak mau memilih pemimpin di luar garis keluarga atau terpilih melalui forum yang memang demi formalitas.
Efek langsung dari pemimpin yang . demikian ini organisasi yang ia pimpin menjadi tak mungkin optimal, tak berkembang, kinerjanya amburadul dan lama kelamaan hancur. Padahal seperti kata Max Weber seabad yang lalu, lembagalembaga yang bertahan hidup termasuk negara tidak disebabkan oleh kharisma seseorang pemimpin atau pemimpin karbitan, tetapi karena mereka menumbuhkan kepemimpinan di seluruh sistem. Karena itu ketiga penulis buku ini kemudian mengajukan tesis pentingnya primal leadeship yang mendasarkan bahwa seorang pemimpin adalah orang yang benarbenar tumbuh dan muncul karena potensinya. Persoalan apakah potensi itu tumbuh secara alami atau melalui berbagai jalur formal itu adalah sebuah proses pengembangan potensi tadi. Jadi proses bukan masalah yang perlu dipertentangkan secara hitam putih, yang jelas pemimpin memang tidak datang dari langit. Ketiga penulis buku ini berpendapat bahwa tugas dasar seorang pemimpin adalah memancing tumbuhnya perasaan yang positiff dałam diri 
orang-orang yang dipimpinnya. Ini akan terjadi jika seorang pemimpin menciptakan resonance sumber sifat-sifat positif yang mampu menggerakkan orang untuk mengeluarkan upaya terbaiknya. Oleh karena itu, pada pokoknya, tugas dasar kepemimpinan bersifat emosi. (him.ix).

Ditambahkan mereka, selama ini aspek emosi pemimpin sering diabaikan karena dianggap remeh temeh, padahal berdasar temuan penelitian mereka justru aspek inj sangat penting. "Kini saatnya untuk diperhatikan," kata mereka. Diyakini bahwa dimensi mendasar kepemimpinan ini akan sangat menentukan apakah yang dilakukan seorang pemimpin akan berhasil sebagaimana mestinya ataukah tidak. Di sinilah kecerdasan emosi (emotional intelligence, El) sangat penting bagi keberhasilan kepemimpinan.

\section{Primal Leadership}

Tugas emosi pemimpin bersifat primal_yang utama_ dalam dua artian: Tugas emosi ini merupakan tindakan yang orisinal sekaligus paling penting dari kepemimpinan.

Pemimpin selalu memainkan emosi yang primordial. Tidak diragukan bahwa para pemimpin yang orisinal entah ia kepala suku atau pemimpin negara, mendapatkan kedudukannya terutama karena kemampuan mereka menggerakkan emosi. Di dalam sejarah dan budaya maria pun, pemimpin kelompok manusia adalah seorang yang menjadi tumpuan dalam mencari kepastian dan kejelasan ketika menghadapi ketidakpastian atau ancaman, atau ketika ada suatu tugas yang harus dilakukan. Pemimpin bertindak sebagai pembimbing emosi kelompok.

Dalam organisasi modern, tugas emosi yang primordial ini tetap merupakan tugas terdepan di antara banyak tugas kepemimpinan lainnya: menggerakkan emosi kolektif ke arah yang positif dan menyingkirkan "kabut asap" yang terbentuk oleh emosi-emosi beracun.

Primal leadership sebenarnya kalau disederhanakan mirip dengan teori anachievementnya David Mclelland. Intinya, jika emosi orang-orang didorong ke arah antusiasme, kinerja akan meningkat; sebaliknya jika emosi orang-orang didorong ke arah kebencian dan kecemasan, kinerja akan merosot. Pada akhirnya primal leadership berkerja demi kebaikan dan keuntungan semua orang, dan kuncinya terletak pada kompetensi kecerdasan emosi sang pemimpin; bagaimana pemimpin menangani dirinya sendiri dan relasirelasinya. Pemimpin yang memaksimalkan manfaar primal leadership akan menggerakkan emosi pengikutnya ke arah yang benar.

\section{Kecerdasan Emosi: Membangun Kompetensi Kepemimpinan}

Lalu apa ciri-ciri pemimpin yang memiliki kompetensi dan bagaimana membangun kecerdasan emosi dalam diri pemimpin itu. Ada empat poin penting yang mereka ajukan yaitu: pertama, Kesadaran Diri. Di sini pemimpin yang memiliki kesadaran diri emosi yang tinggi dapat mendengarkan tanda-tanda di dalam diri mereka sendiri, mengenai bagaimana perasaan mereka mempengaruhi diri dan kinerja mereka. Mereka mendengarkan dan menyelesaikan diri dengan nilai-nilai yang membimbingnya dan seringkali secara naluriah dapat menentukan tindakan yang terbaik, melihat gambaran besarnya dalam situasi yang kompleks. Pemimpin yang sadar diri emosional bisa tegas dan otentik, mampu berbicara terbuka tentang berbagai 
hal dilandasi keyakinan tentang visi yang membimbing mereka. Pemimpin demikian ini juga menyadari benar kelemahan sekaligus kelebihan dirinya. Karena itu ia senantiasa cerdas dalam menangkap isu negatif tentang dirinya atau di dalam menerima kritik setajam apapun. Bahkan pada momentum yang tepat la mampu dengan cepat membalikkan keadaan "terpuruk" menjadi bangkit kembali. Dan ia mampu memotivasi bawahannya sedemikian rupa sehingga tetap survive di tengah kesulitan.

Kedua, pengelolaan diri. Ciri ini menonjol karena pemimpin model ini berpenampilan tenang, berpikiran jernih kendati dibawah tekanan berat/keras. la juga memiliki sifat tranparansi, suatu keterbukaan yang otentik kepada orang lain tentang perasaan, keyakinan, dan tindakan seseorang sehingga membawanya menjadi orang yang memiliki integritas kuat. Kelebihan lain ia cepat beradaptasi, memiliki inisiatif dan senantiasa optimis melihat ke depan.

Ketiga, kesadaran sosial. la memiliki empati mampu mendengarkan tidak sekadar dari telinga tetapi dengan mata hatinya. Baginya pemimpin memberi karena diminta itu hal biasa, tetapi menjadi pemimpin memberi sẹbelum diminta karena memang dibutuhkan oleh rakyatnya itu yang menjadi prinsip empatinya.

Keempat, pengelolaan relasi. Dalam pengelolaan diri ada enam poin yang senantiasa menjadi pegangannya yaitu: menjadi inspirator, mampu mempengaruhi orang lain, mampu mengembangkan potensi orang lain, menjadi katalisator perubahan, baik dalam pengelolaan konflik (manajemen konflik) dan mampu bekerja dalam tim dan berkolaborasi secara profesional.

Kesemua ciri ini melekat pada diri seorang pemimpin (primal leadership). Di Indonesia yang tengah menantikan sosok pemimpin yang tepat, nampaknya akan sulit mendapat pemimpin dengan kriteria demikian. Tetapi paling tidak kita dapat meramu sosok yang demikian ini dengan melihat sepak terjangnya (track record) selama ini. Barangkali pemimpin demikian bisa diakomodasikan dari kriteria pendidikannya yang baik, lama aktif di organisasj keagamaan dan senantiasa terjaga dari segala bentuk KKN dan memiliki pendukung yang mengharap ia dapat mengatasi keadaan terutama seberat yang dihadapi Indonesia saat ini.

Buku ini layak dibaca oleh siapapun terutama para politisi, dosen, mahasiswa dan praktisi bidang SDM. 